\title{
DAYA DUKUNG HIJAUAN PAKAN DALAM KONSERVASI SAPI PUTIH TARO
}

\author{
I W. Suarna, M.A.P. Duarsa, N.P. Mariani, L.G. Sumardani, dan S.A.Lindawati \\ Puslitbang Tumbuhan Pakan Universitas Udayana \\ puslitbangtp@gmail.com, suarnawyn@yahoo.com
}

\begin{abstract}
White cattle Taro is a Bali native germplasm that must be preserved in accordance with the mandate of the Millennium Development Goals to reduce the rate of loss of biodiversity as a valuable genetic resources. At this time, the population of White cattle Taro is 34 heads, which the conditions still cause for concern because of the increasing pressure of various factors. When the white cattle graze in their natural habitat (forest Taro) White cattle Taro to reach a population of 150 animals (2001). Pressure against white cow increasingly widespread because the land is narrow and increasing the amount of forage that should be provided in rotation by traditional society village of Taro. Taro village located in District Tegallalang, close to Districts Payangan Gianyar regency. Two districts are developing leading commodity Bali cattle. While White cattle Taro also requires the availability of forage species are the same as Bali cattle. The results showed that carrying capacity of forage for White cattle Taro started to decline so that the necessary strategic approach to the conservation of taro white cattle in order to accelerate the achievement of the millennium development. Such efforts are: 1) improving the efficiency of forage production 2) optimizing the utilization of forage 3) optimization of land use and cultivation of superior feed and 4) technological capacity building of local feed plant.
\end{abstract}

Keywords: white cattle Taro, carrying capacity of forage and conservation

\begin{abstract}
Abstrak
Sapi Putih Taro adalah plasma nutfah asli Bali yang harus dilestarikan sesuai dengan amanat Tujuan Pembangunan Millenium untuk mengurangi laju kehilangan keanekaragaman hayati sebagai sumberdaya genetik yang sangat berharga. Sapi putih Taro saat ini populasinya sebanyak 34 ekor dengan kondisi masih memprihatinkan karena meningkatnya tekanan dari berbagai faktor. Ketika sapi putih menggembala di habitat aslinya (hutan Taro) sapi putih taro dapat mencapai populasi sebanyak 150 ekor (Tahun 2001). Tekanan terhadap sapi putih semakin meluas karena lahan yang menyempit dan meningkatnya jumlah hijauan yang harus disediakan secara bergilir oleh mayarakat adat Desa Taro. Desa Taro terletak di Kecamatan Tegalalang, berdekatan dengan kecamatan Payangan Kabupaten Gianyar. Kedua kecamatan tersebut mengembangkan komuditas unggulan sapi bali. Sementara sapi taro juga membutuhkan ketersediaan spesies hijauan yang sama dengan sapi bali. Hasil penelitian menunjukkan bahwa daya dukung hijauan pakan untuk sapi putih taro mulai menurun sehingga diperlukan pendekatan strategis dalam pelestarian sapi putih taro dalam rangka mempercepat pencapaian pembangunan millenium. Upaya tersebut adalah: 1) meningkatkan efisiensi produksi hijauan 2) optimalisasi pemanfaatan hijauan pakan 3) optimalisasi pemanfaatan lahan dan budidaya tanaman pakan unggul dan 4) teknologi peningkatan kapasitas tanaman pakan lokal.
\end{abstract}

Kata kunci: sapi putih taro, daya dukung hijauan, dan konservasi 


\section{Pendahuluan}

Memastikan kelestarian lingkungan hidup merupakan salah satu tujuan dari delapan tujuan pembangunan milineum (Millenium Development Goals = MDGs). Salah satu fokus kegiatan pada aspek melestarikan lingkungan hidup adalah mengurangi kehilangan sumberdaya hayati. Bali memiliki cukup banyak sumberdaya hayati yang beberapa di antaranya sudah mengalami kepunahan dan nyaris punah. Harimau Bali dan itik bali sudah tidak ditemukan lagi, sedangkan babi Bali, kakatua jambul kuning, kambing gembrong, jalak Bali kondisinya nyaris punah. Sapi putih Taro yang sering disebut lembu putih Taro hanya ada di Desa Taro, Kecamatan Tegalalang, Kabupaten Gianyar dan dimanfaatkan untuk kepentingan upacara agama di seluruh Bali. Terkait dengan komitmen dan program Pemerintah Provinsi Bali untuk melaksanakan percepatan pelaksanaan pencapaian tujuan MDGs sesuai Roadmap MDGs Bali, maka dukungan terhadap pelestarian lembu putih mutlak diperlukan.

Dalam konteks konservasi sapi putih Taro terdapat berbagai aktivitas riset yang harus dilakukan seperti studi tentang aspek genomic sapi putih Taro, behaviour, teknologi budidaya termasuk aspek penyediaan pakannya. Berdasarkan atas tata guna lahan, komuditas ternak unggulan, dan perkembangan pembangunan masyarakat Desa Taro maka sangat dipandang perlu mencermati seberapa besar daya dukung hijauan pakan terhadap keberlanjutan asset plasma nutfah sapi putih Taro. Daya dukung hijauan pakan dikaji dengan tujuan untuk mengidentifikasi permasalahan ketersediaan hijauan untuk sapi putih Taro di tengah-tengah meningkatnya tekanan terhadap sumberdaya plasma nutfah Indonesia.

\section{Metode Penelitian}

Penentuan lokasi menggunakan pendekatan Location Driven (kawasan yang memiliki potensi dan daya dukung memadai untuk pengembangan suatu komoditas unggulan), yang ditetapkan keunggulan komparatifnya dengan metode $L Q$ (Location Quatient) (Permentan No 50 Th 2012). Komponen utama yang dipertimbangkan: potensi lahan pertanian, sebaran komoditas unggulan, dan potensi pengembangan komoditas unggulan, yang diperoleh dengan pelaksanaan survei, dan dianalisis secara deskriptif. Pengukuran produksi hijauan menggunakan dry-weight rank method.

Status daya dukung hijauan pakan pendekatannya dicoba untuk memanfaatkan penentuan status daya dukung lahan dimana:

1) status daya dukung lahan terhadap ketersediaan hijauan pakan diperoleh dari pembandingan antara ketersediaan lahan $\left(\mathrm{S}_{\mathrm{L}}\right)$ dan kebutuhan lahan $\left(\mathrm{D}_{\mathrm{L}}\right)$;

2) bila $S_{L}>D_{L}$ maka daya dukung lahan dinyatakan surplus;

3) bila $S_{L}<$ DL maka daya dukung lahan dinyatakan defisit atau terlampaui.

\section{Hasil dan Pembahasan}

\subsection{Kondisi Eksisting Sapi Putih Taro}

Sapi putih Taro sangat rentan terhadap kondisi hujan dan panas. Demikian pula apabila dibiarkan lepas (diumbar) maka sifat dominansinya terhadap sesama jenis akan muncul sehingga nampak sebagai penomena sadisme pada ternak. Luas lahan hutan adat saat ini mencapai 24 ha dengan luasan lahan penggembalaan sapi (ranch) sekitar 4 ha. Kemungkinan lembu mendapatkan makanan di dalam kandangnya secara alami sangat minim, karena rerumputan yang ada dan tumbuh di sini sudah sangat tipis, sehingga harus mendapat suplai dari luar kadang. Pemberian makanan setiap hari dilakukan oleh sekitar 10 orang anggota masyarakat yang bertugas memberikan makan dan mencarikan rumput di sekitar hutan. Masyarakat yang bertugas membawakan hijauan pakan sampai di kandang sebanyak 6 orang setiap hari, yang dilaksanakan secara bergiliran (Suarna et al. 2014).

Lembu putih merupakan sapi yang secara endemik terdapat di Desa Taro, Kabupaten Gianyar. Sapi tersebut dipelihara oleh masyarakat adat Desa Taro dan dimanfaatkan oleh masyarakat Hindu di seluruh Bali untuk kepentingan pelaksanaan upacara keagamaan (piranti upakara). Untuk tetap lestarinya lembu putih, baik sebagai sumber plasma nuftah ataupun sebagai warisan budaya yang memiliki mitologi sebagai basis kearifan lokal, maka peran pemerintah daerah kabupaten dan provinsi demikian pula majelis desa pakraman sangat diperlukan untuk mendukung upaya pelestarian lembu putih tersebut. Program nasional seperti SDGs dan MP3EI juga mengisyaratkan bahwa pelestarian terhadap lembu 
putih merupakan upaya memastikan menurunnya kehilangan sumberdaya hayati. Revitalisasi terhadap kearifan lokal masyarakat setempat, luasan dan vegetasi hutan, dan nilai historis lembu putih taro akan meningkatkan potensi sumberdaya tersebut untuk dapat meningkatkan kesejahteraan masyarakat setempat dengan mewujudkan lembu putih Taro sebagai salah satu tujuan kunjungan wisata (Suarna, 2014).

Pada tahun 1967 terjadi konversi (pengalihfungsian) hutan yang menjadi komunitas lembu putih. Mitos yang berkembang biasanya bermanfaat efektif sebagai mekanisme kontrol terhadap lingkungan. Namun di Desa Taro yang dulu memiliki Alas Duwe (hutan taro) dengan sapi putih yang berkembang biak di dalamnya, sebagian telah dialihfungsikan menjadi lahan pertanian dengan membabat hutan, sedangkan lembu putih dibiarkan berkeliaran di kampung-kampung.

Lembu putih Taro pada awalnya dibiarkan lepas dan tidak dikandangkan. Lembu ini berkeliaran di Banjar Taro Kaja, namun akhir-akhir ini puluhan lembu putih tersebut telah dikurung di dalam ranch dengan ukuran sekitar seluas lapangan sepak bola, yang letaknya di ujung selatan Banjar Taro Kaja.
Menurut Kelihan Adat Banjar Taro Kaja (narasumber : I Gede Riwa), Ketika lembu tersebut diumbar di kawasan hutan Taro populasinya dapat mencapai 150 ekor pada tahun 2000. Populasi sapi putih pada akhir tahun 2014 tercatat sebanyak 34 ekor.

\subsection{Ketersediaan Pakan}

Jenis tanaman yang ada di padang gembalaan sapi putih (4 ha) sebagian besar tanaman lokal seperti Brachiaria repens, Stenotaphrum sp, Soizia matrella, dan Centrocema sp. Sedangkan Arachis pintoi dan Stenotaphrum secundatum baru diinroduksi pada lahan pengembalaan tersebut. Produksi hijauan pada padang gembalaan tersebut hanya cukup untuk 4 ekor sapi saja (29.565 kg segar) per tahun. Sehingga diperlukan pasokan hijauan yang diperoleh dari masyarakat secara bergiliran.

Hijauan yang disediakan masyarakat terdiri atas: rumput raja, rumput gajah, dan terkadang ada yang memberikan gamal. Berkurangnya lahan hutan, adanya wisata gajah, dan meningkatnya populasi sapi Bali yang dipelihara masayarakat Desa Taro dapat mengurangi ketersediaan hijauan pakan untuk sapi putih taro.
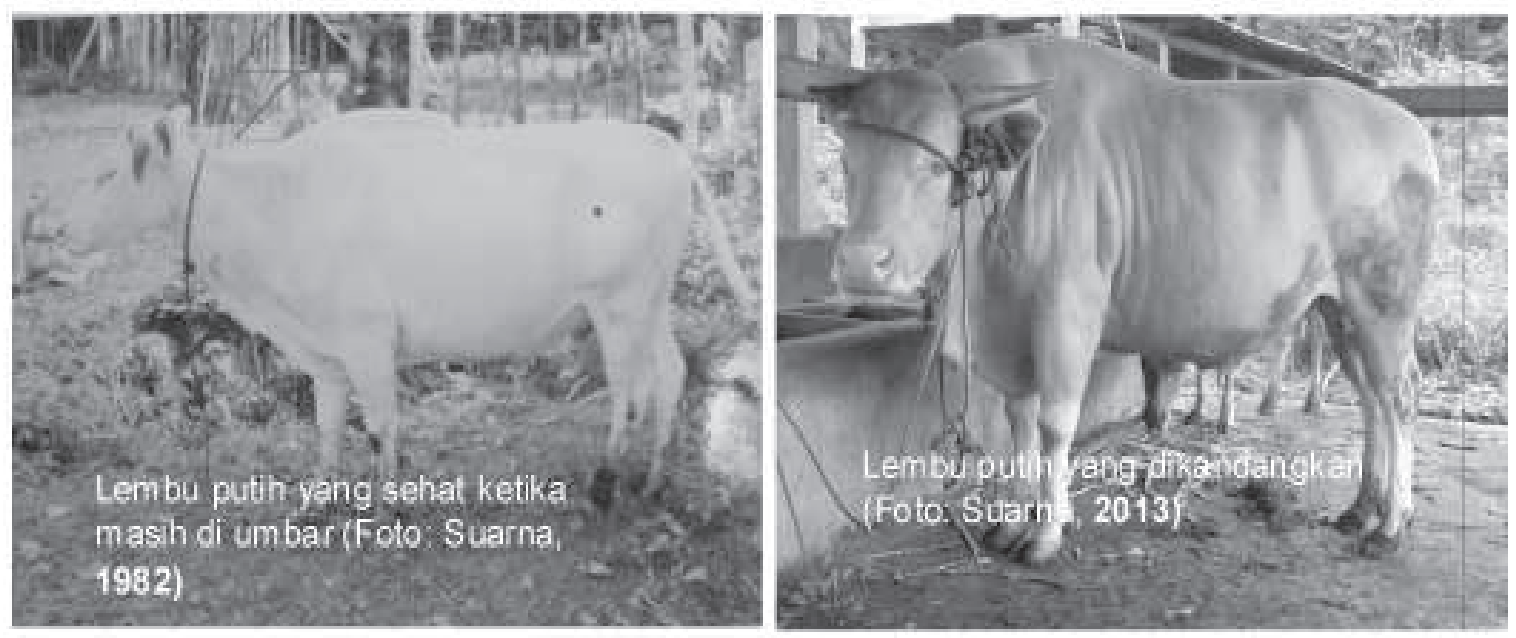

Gambar 1: Penampilan Sapi Putih Taro 
Tabel 1. Populasi Ternak Sapi Bali di Kecamatan Tegalalang Tahun 2013

\begin{tabular}{|c|c|c|c|c|c|c|c|c|c|c|c|c|}
\hline \multirow{3}{*}{ No } & \multirow{3}{*}{$\begin{array}{c}\text { Desa/ } \\
\text { Kelurahan }\end{array}$} & \multicolumn{4}{|c|}{ SAPI BALI JANTAN } & \multicolumn{6}{|c|}{ SAPI BALI BETINA } & \multirow{3}{*}{ Jumlah } \\
\hline & & \multirow[b]{2}{*}{ Anak } & \multirow[b]{2}{*}{ Muda } & \multirow[b]{2}{*}{ Dewasa } & \multirow[b]{2}{*}{ Jumlah } & \multirow[b]{2}{*}{ Anak } & \multirow[b]{2}{*}{ Muda } & \multicolumn{3}{|c|}{ Dewasa } & \multirow[b]{2}{*}{ JUMLAH } & \\
\hline & & & & & & & & $\begin{array}{c}2-4 \\
\text { tahun }\end{array}$ & $\begin{array}{l}5-6 \\
\text { tahun }\end{array}$ & $\begin{array}{l}>6 \\
\text { tahun }\end{array}$ & & \\
\hline 1 & Tegallalang & 45 & 70 & 59 & 174 & 36 & 47 & 56 & 60 & 27 & 226 & 400 \\
\hline 2 & Kendran & 3 & 4 & 4 & 11 & 74 & 98 & 116 & 125 & 64 & 477 & 488 \\
\hline 3 & Kedisan & 18 & 29 & 25 & 72 & 86 & 114 & 136 & 147 & 76 & 559 & 631 \\
\hline 4 & Sebatu & 76 & 123 & 107 & 306 & 112 & 147 & 176 & 190 & 96 & 721 & 1.027 \\
\hline 5 & Pupuan & 356 & 567 & 482 & 1.405 & 201 & 266 & 319 & 345 & 173 & 1.304 & 2.709 \\
\hline 6 & Taro & 414 & 630 & 562 & 1.606 & 356 & 472 & 564 & 612 & 311 & 2.315 & 3.921 \\
\hline 7 & Keliki & 44 & 69 & 59 & 172 & 64 & 85 & 102 & 110 & 56 & 417 & 589 \\
\hline \multicolumn{2}{|c|}{ Jumlah 2013} & 956 & 1.492 & 1.298 & 3.746 & 929 & 1.229 & 1.469 & 1.589 & 803 & 6.019 & 9.765 \\
\hline
\end{tabular}

Tabel 2. Nilai LQ Berbagai Jenis Ternak di Kabupaten Gianyar Tahun 2013

\begin{tabular}{|c|c|c|c|c|c|c|c|}
\hline Sapi & Gianyar & Blahbatuh & Sukawati & Ubud & Payangan & Tegalalang & Tampaksiring \\
\hline LQ & 0,6 & 1,8 & 0,25 & 0,5 & 1,61 & 1,62 & 0,89 \\
\hline Babi & Gianyar & Blahbatuh & Sukawati & Ubud & Payangan & Tegalalang & Tampaksiring \\
\hline $\mathbf{L Q}$ & 0,51 & 0,67 & 0,71 & 0,99 & 1,91 & 1,07 & 0,78 \\
\hline Kambing & Gianyar & Blahbatuh & Sukawati & Ubud & Payangan & Tegalalang & Tampaksiring \\
\hline $\mathbf{L Q}$ & 3,93 & 0,41 & 0,51 & 0,34 & 0,14 & 0 & 0 \\
\hline Ayam Buras & Gianyar & Blahbatuh & Sukawati & Ubud & Payangan & Tegalalang & Tampaksiring \\
\hline $\mathbf{L Q}$ & 0,44 & 0,73 & 1,24 & 0,39 & 1,12 & 1,46 & 1,44 \\
\hline Itik & Gianyar & Blahbatuh & Sukawati & Ubud & Payangan & Tegalalang & Tampaksiring \\
\hline LQ & 1,46 & 1,05 & 0,89 & 0,98 & 0,6 & 0,72 & 1,34 \\
\hline $\begin{array}{l}\text { Ayam Ras } \\
\text { Pedaging }\end{array}$ & Gianyar & Blahbatuh & Sukawati & Ubud & Payangan & Tegalalang & Tampaksiring \\
\hline LQ & 1,57 & 1,29 & 0,99 & 1,52 & 0,6 & 0,65 & 0,63 \\
\hline $\begin{array}{l}\text { Ayam ras } \\
\text { Petelur }\end{array}$ & Gianyar & Blahbatuh & Sukawati & Ubud & Payangan & Tegalalang & Tampaksiring \\
\hline LQ & $\mathbf{0}$ & 0 & 0 & 2,45 & 3,78 & 0 & 0 \\
\hline Domba & Gianyar & Blahbatuh & Sukawati & Ubud & Payangan & Tegalalang & Tampaksiring \\
\hline LQ & 3,93 & 0,41 & 0,51 & 0,34 & 0,14 & 0 & 0 \\
\hline Babi Bali & Gianyar & Blahbatuh & Sukawati & Ubud & Payangan & Tegalalang & Tampaksiring \\
\hline LQ & 0 & 1,17 & 0,93 & 0 & 0,33 & 4,38 & 0,51 \\
\hline
\end{tabular}


Sapi putih taro terdapat di Desa Taro Kaja, Kecamatan Tegalalang Kabupaten Gianyar. Komuditas unggulan Kecamatan Tegalalang adalah sapi Bali. Pada Tabel 2 di atas terlihat, bahwa pemeliharaan sapi Bali terbanyak di Kabupaten Gianyar adalah di Kecamatan Tegalalang dengan nilai $\mathrm{LQ}=1,62$. Kecamatan Tegalalang selain memiliki sapi putih taro yang dilindungi, juga memiliki plasma nutfah babi Bali dan terbanyak populasinya dibandingkan dengan kecamatan lainnya. LQ untuk babi Bali adalah 4,38. Peningkatan populasi sapi Bali akan meningkatkan penyediaan pakan hijauan, demikian pula peningkatan populasi sapi putih Taro.

\subsection{Kebutuhan Hijauan Untuk Sapi Bali}

Kebutuhan hijauan pakan untuk sapi putih per tahun mencapai $221.738 \mathrm{~kg}$ hijauan segar. Sapi putih karena dipelihara di dalam kandang tidak dapat memanfaatkan hijauan pakan dari hutan pada habitat aslinya. Pemeliharaan sapi putih saat ini sudah dilaksanakan dengan menajemen dari yayasan yang dibentuk oleh masyarakat Desa Taro. Sapi Taro saat ini sedang dikemas untuk wisata sapi putih berdampingan dengan wisata gajah. Populasi sapi putih sudah mengalami peningkatan lagi hingga pada ahkir tahun 2014 berjumlah 34 ekor. Peningkatan populasi ternak tentunya akan meningkatkan kebutuhan pakan hijauan.

Penyediaan hijauan pakan untuk ternak ruminansia di Kabupaten Gianyar masih sangat kurang dan banyak petani peternak yang memanfaatkan jerama padi sebagai pakan serat utama bagi ternak sapinya. Kendala pengembangan hijauan pakan di Kaupaten Gianyar menurut Suarna dan Suryani (2013) adalah:

1. meningkatnya alih fungsi lahan;

2. hijauan pakan belum diolah secara bisnis;

3. pemanfaatan lahan untuk penanaman hijauan belum optimal;

4. budidaya tanaman pakan unggul belum banyak dilakukan;

5. teknologi peningkatan kualitas tanaman pakan lokal belum banyak diterapkan, dan

6. belum tersedia data ang cukup tentang jenis tanaman pakan yang potensial dikembangkan.

Mengembalikan lembu putih ke habitat aslinya dapat memperbanyak populasi lembu putih dan sapi akan terlihat sehat karena bebas bergerak dan mendapat pakan beranekaragam. Riset sumber bahan pakan untuk ternak ruminansia termasuk sapi telah membuktikan bahwa meningkatnya keberagaman sumber hijauan pakan akan dapat meningkatkan aktivitas mikrobia rumen sapi sehingga konversi pakan menjadi semakin baik (nilai Feed Conversion Rasio menjadi semakin kecil). Sinergisme antara kepentingan wisata gajah, hutan desa, budidaya tanaman masyarakat, dan pelestarian habitasi lembu putih perlu diupayakan agar pengarusutamaan lingkungan dalam berbagai aspek pembangunan dapat diwujudkan dengan serasi dan harmonis. Upaya yang diperlukan untuk meningkatkan daya dukung hijauan pakan untuk pengembangan sapi putih taro adalah melalui pengadaan dan perbaikan vegetasi hutan dan pemanfaatan lahan perkebunan yang ditumpangsarikan dengan tanaman pakan. Sebagian besar tumbuhan di bawah lahan perkebunan dapat dimanfaatkan sebagai sumber hijauan pakan tetapi produktivitasnya masih rendah. Strategi penyediaan hijauan pakan memerlukan pendekatan/dukungan seperti berikut:

1. meningkatkan jumlah, jenis, dan efektivitas berbagai kebun bibit;

2. melibatkan berbagai pemangku kepentingan;

3. meningkatkan efektivitas pemanfaatan sumber daya untuk pengembahan tumbuhan pakan;

4. menerapkan prinsip-prinsip bioteknologi lingkungan dalam, dan pembudidayaan dan pengolahan HMT.

\section{Simpulan dan Saran}

\subsection{Simpulan}

1) Hutan Desa Taro yang cukup luas perlu direvitalisasi sehingga sapi putih dapat dilepas secara teratur dan berencana untuk meningkatkan behaviour sapi putih;

2) Upaya konservasi sapi putih Taro harus didukung dengan upaya pemanfaatan dan pengembangan HMT secara berkelanjutan;

3) Komoditas sapi Bali sebagai komuditas unggulan di Kecamatan Tegalalang, Kabupaten Gianyar harus dapat dikembangkan secara sinergis dengan upaya pelestarian dan konservasi sapi putih Taro. 
4.2 Saran

1) Perlu dipertimbangkan untuk pengadaan kebun hijauan yang khusus diperuntukkan dalam rangka konservasi sapi putih taro (jika sapi putih tidak dilepas/dipelihara di kandang);

2) Renovasi padang gembalaan dengan menambah pohon penaung merupakan upaya yang tepat untuk konservasi sapi putih Taro.

\section{Daftar Pustaka}

Permentan No 50. 2012. Pedoman Pengembangan Kawasan Pertanian. Menteri Pertanian Republik Indonesia.
Suarna, I.W. 2014. Peternakan Yang Menekan Pencemaran. Arti Foundation. Denpasar

Suarna I W. dan N.N. Suryani. 2013. Potensi dan Pengembangan Tanaman Pakan pada Lahan Perkebunan di Kabupaten Gianyar Provinsi Bali. Prosiding Semnas II HITPI di Denpasar.

Suarna, W., K.M. Budiasa, I W. Wirawan, dan N.L.G. Sumardani. 2014. " Daya Dukung Lahan dan Tumbuhan Pakan dalam Pengembangan Komuditas Unggulan Peternakan di Kabupaten Gianyar" dalam Jurnal Pastura. 4 (1): 51 -55. 